\title{
WILDLIFE ART
}

UY LY, 3614 Dewdney Avenue, Regina, Saskatchewan. S4T 0Z5

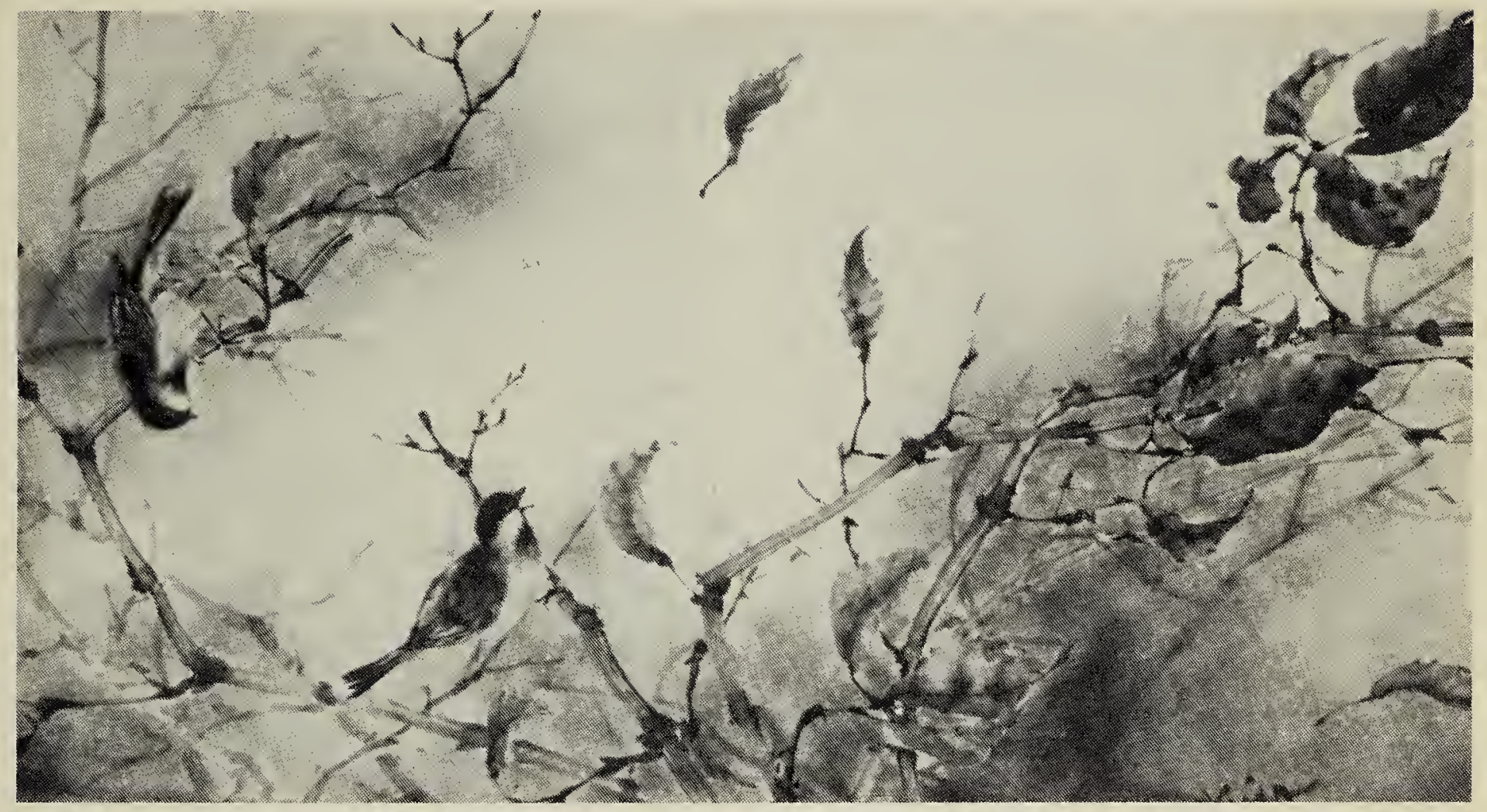

Black-capped Chickadee.

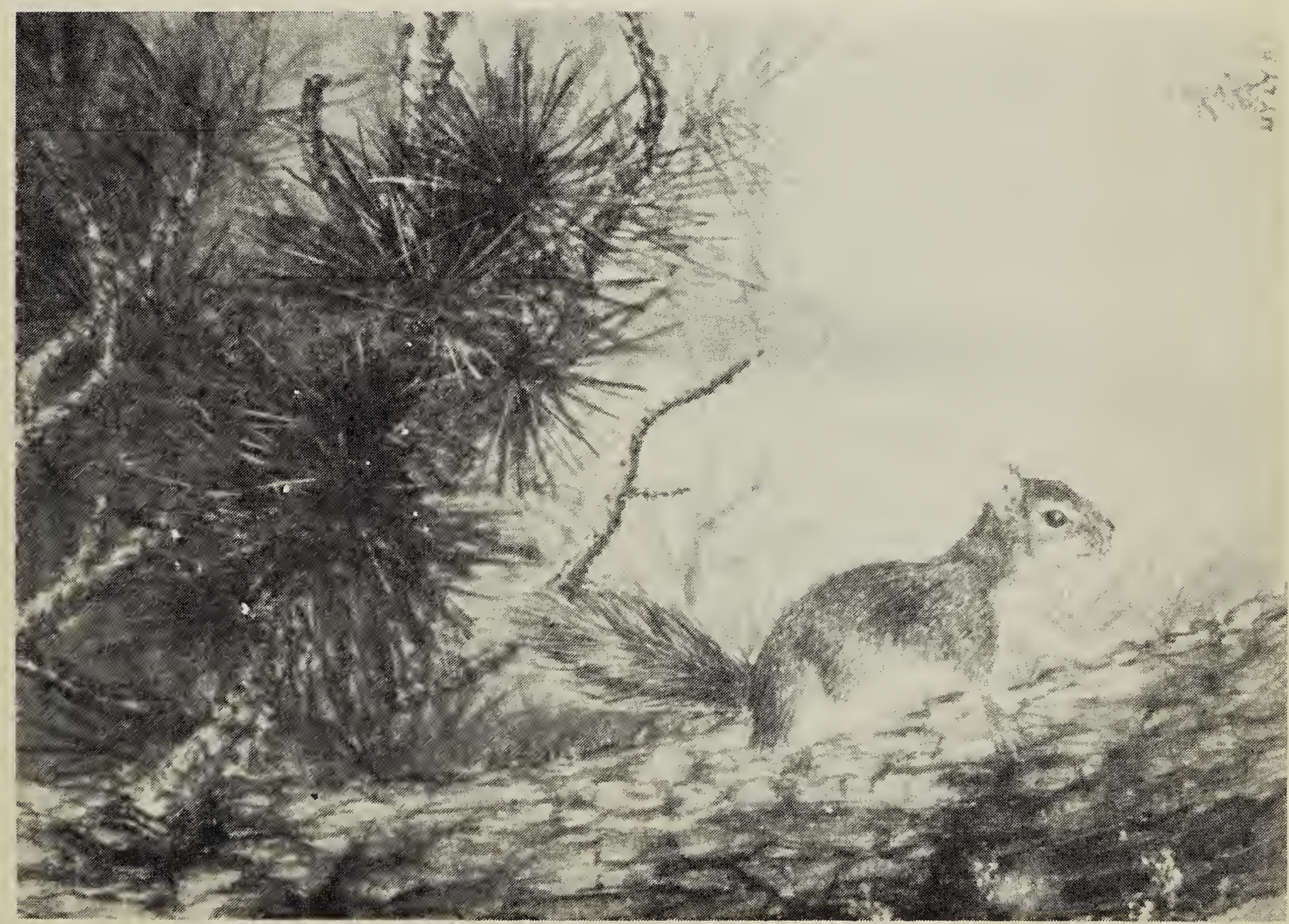

Red Squirrel. 